\title{
Current status and strategies for conservation of double hump camel (Camelus dromedarius) in Ladakh, India
}

\author{
S. Vyas*, U.K. Bissa
}

ICAR- National Research Centre on Camel, P.B. 07, Bikaner- 334001 INDIA

*Corresponding author email: sumantv@mail.com

Journal of Livestock Science (ISSN online 2277-6214) 12: 132-137

Received on 3/10/2019; Accepted on 12/12/2019

doi. 10.33259/JLivestSci.2019.132-137

\begin{abstract}
The Camelus bactrianus also known as double hump camel are habitat of Central Asia. Historically they were effective means of transportation for trade in the silk route connecting Central Asia and also between Tibet and Ladakh in India. This route was closed after Indo- China conflict in 1962 and Bactrian camel lost their importance. Recently their use in tourism and as draft animal in strategic locations has opened new avenues. The present paper is an attempt to provide information about current status and strategies for conservation of Indian double hump camel.
\end{abstract}

Key words: current status; conservation; tourism; Camelus bactrianus; Ladakh, India 
The Camelus bactrianus is also known as type of camel with two humps. But in most of Europe it is known as Camel and single hump camel is known as dromedaire or dromedary camel. The word bactrianus in Camelus bactrianus comes from Bactria, a kingdom at the foot of the Hindu Kush Mountains of ancient Persia (Lensch, 1999). The Bactrian camels are mostly confined in high land of Central Asian countries viz. Mongolia, China, Kazakhstan, Turkmenistan, North-Eastern Afghanistan, Uzbekistan and to lesser extent in Pakistan, Iran and Turkey ( He 2002; Indra et al, 2003; Isani \& Baloch, 2000; Moqaddam \& Namaz-Zadah, 1988). The Bactrian camel was principal means of transport across $6400 \mathrm{~km}$ historic "silk route", the bridge between the eastern and western cultures. In addition to transport the camel provides valuable products like wool, meat and milk and is of great value to the people who inhabit the cold arid desert regions (Dong, 1984). Bactrian camels move at about $5 \mathrm{~km} / \mathrm{hr}$, produce $5 \mathrm{~kg}$ of hair/year, $600 \mathrm{lt}$ of milk /year and $250 \mathrm{~kg}$ of dung / year (Shergojry et al. 2017).

Camel caravans carried tea, silk and porcelain of China to the bazaars in the Middle East and as far as the Byzantine empire and Rome. Italian traveler and businessman Marco Polo traveled on the Silk Route several times from 1271 to 1295. He introduced Europe to Bactrian Camel. Traders from Central Asian countries such as Mongolia and Kazakhstan, also used the camels to carry heavy loads of their merchandise along the rugged terrain of the trade route to Ladakh and from Ladakh to the adjoining cold desert regions via the Karakoram pass.

Kashmiri historian Haji Abdul Razzaq Jamshed wrote in his book The Tale of Nubra Valley that the Bactrian camel appeared in Ladakh in 1870. It was introduced as a draught animal in Ladakh by travellers of Yarkland in the 19th century. Another view or folklore is that they were first introduced in Kashmir by Hazrat Mir Sayeed Ali Hamdani, a revered Sufi saint. When he, along with 700 companions, travelled to Kashmir for the first time in $872 \mathrm{AD}$, they used these camels to cross the cold desert from Iran via the silk route that stretched from Sian in China to Antioch in Syria. Subsequent trips in 874 ad and $876 \mathrm{AD}$ were also made on these animals. Due to the absence of roads, the camels became the ideal mode of transportation. Later, tribes like the Barcha, Chonjor, Kalon, Shanku and Shaban on the Indian side of the border also bred and maintained the animals and used them extensively for carrying goods and merchandise.

Even after closing of the Karakoram route connecting Yarkand in northwest China, these animals were used for transport across Changla via Durbook and the Changtang part of Tibet. But following the Chinese aggression in 1962, this route was stopped completely and camel lost its importance. The presence of roads undermined the utility of the camel as a mode of transport, and rearing and maintaining them became increasingly unprofitable in and around Leh. Eventually, the animals were shifted to Nubra Valley situated at 10000 to $12000 \mathrm{ft} \mathrm{msl}$, which is rich in foliage. In all, about 60 camels were shifted to Nubra from Leh by 1965.

The total area falling under cold desert in India is approximately $74809 \mathrm{sq} . \mathrm{km}$. and lies between $31^{\circ} 44^{\prime} 57^{\prime \prime}-36^{\circ} \mathrm{N}$ and $75^{\circ} 15^{\prime}-80^{\circ} 15^{\prime} \mathrm{E}$ and has extremes of cold temperature ranging from $10^{\circ} \mathrm{C}$ to $40^{\circ} \mathrm{C}$ in winter and $40^{\circ} \mathrm{C}$ to $-10^{\circ} \mathrm{C}$ in summer. The arid area of this cold region has very coarse, porous and immature sand particles and suffer to wind and water erosion. The climate of the area is more harsh because of intense infra and ultraviolet radiations, low pressure of atmospheric oxygen and carbon dioxide, low rainfall of about 2 to $14 \mathrm{~mm}$ and very sparse vegetation during winter but luxuriant wild vegetation, mainly Sea Buckthorn (Hippophae rhamnoides) available during April to August months of summer (Vyas et al., 2014)

Bactrian camel is adapted to arid plains and hills where water sources are few and vegetation is sparse, often little beyond some drought-resistant shrubs. These camels are migratory, and their habitat ranges from rocky mountain to flat arid desert, stony planes and sand dunes. The camels' distribution is linked to the availability of water, with large groups congregating near rivers after rain or at the foot of the mountains, where water can be obtained from springs in the summer months, and in the form of snow during the winter. Similarly Bactrian camels belong to a fairly small group of animals who eat snow. In autumn and winter, the camel can meet part of its water requirement through snow intake. The animals living above the snowline are obliged to do this as snow and ice are the only forms of water during winter. The latent heat of snow and ice is enormous compared with the heat capacity of water, demanding a large sacrifice in heat energy and forcing animals to eat only small amounts at a time.

An average bactrian camel stands 6 to 7.5 feet (1.8 to 2.3 meters) in height and weighs between 1,000 and 1,575 pounds (455 and 715 kilograms). The long, wooly coat varies in colour from dark brown to sandy beige. There is a mane and beard of long hair on the neck and throat, with hairs up to $25 \mathrm{~cm} / 10$ inches long. The shaggy winter coat is shed extremely rapidly, with huge sections peeling off at once, 
almost as if it were shorn off. There are two humps on the back, which are composed of fat. The face is long and somewhat triangular, with a split upper lip. There are long eyelashes, which, along with the sealable nostrils, help to keep out dust in the frequent sandstorms which occur. The two broad toes on each foot have undivided soles and are able to spread widely as an adaptation to walking on sand. The coat of a wild bactrian camel is short and gray-brown in colour; that of a domestic or tame version of the animal is long and dark brown.

Owing to the difficult accessibility, mostly high altitude and extreme climate of its habitat the Bactrian camel (Camelus bactrianus) has so far been largely neglected by researchers. Estimates of Bactrian camels are scant. The FAOSTAT does not provide population of Bactrian camel and has clubbed it with dromedary camel. Similarly, the Livestock Census by Government of India also did not provide information about its population. The number of double-humped camels revealed by door-to-door survey conducted by the Department of Animal Husbandry, Ladakh was 56 in 1964, 32 in 1978 and 47 in 1986 (Khanna \& Khan 1988). NRC on camel Bikaner, conducted studies during an ICAR AP-Cess fund scheme on "Evaluation and conservation of double humped Camel in cold desert region."According to initial survey during 1996 the population of double humped camel (Came/us bactrianus) was found to be 76 confined to the 4-5 villages of the Nubra valley of Ladakh, situated at an altitude of 10,000 to 12,000 ft MSL. There were around 150 camels in Nubra in 2012. Three years later, there were 211. The largest population of double humped camel is in the Hunder village followed by Sumoor, Diskit and Tigger (Vyas et al 2015). As per latest Livestock Census 2019 the camel population in Jammu and Kashmir (J \& K) is 470. Since dromedary camel are not available in $\mathrm{J} \& \mathrm{~K}$ so it is safe to presume that this data is for Bactrian camel. The IUCN has declared the camel critically endangered since 1998, yet no serious measures have been adopted to conserve this species (Makhdoomi et al. 2013).

Alarmed by the rapid decline in double-humped camel numbers, a number of measures were initiated both by the state government as well as local organizations to rejuvenate the Bactrian camel population. Unfortunately, most measures were either abandoned mid-way or proved ineffectual. According to the state animal husbandry department's records, the first survey of Yarkandi camels and the people who reared them was carried out by a working group on development of cold desert in September 1986. It was a door-to-door survey that sought to encourage the local people to rear the animal. Local residents showed little enthusiasm towards the proposal as maintaining the animals outweighed their utility. Finally, the survey had to be dropped. A couple of years after this survey, in 1988, the animal husbandry department purchased four camels from local breeders at the rate of Rs 1,500 per animal in an attempt to raise these camels and help them multiply. But this exercise also failed as the scientific program needed to preserve the breed did not follow. The budget for maintenance of Government Camel Farm at Chuchot near Leh is very meager only INR 0.9 million per annum.

\section{Tourism}

The Bactrian Camels were on the verge of extinction till the enterprising residents of the Hunder Village in Nubra Valley took the mantle of saving them. Since the early 2000s though, the number of the Bactrian camels in Nubra has increased, thanks to the residents of the Hunder village in the valley. In 2003, the villagers after noticing a good influx of tourists in Nubra valley decided to launch Bactrian camel safaris. When few farmers started out with the camel safaris, people ridiculed them, saying tourists wouldn't travel so far from Leh for a camel ride. But their struggle has resulted in entirely new tourist destination in Ladakh. This became an instant hit with the tourists and people now have to wait patiently to get their chance for camel safari. There are around 45 families in Hunder conducting these rides. To attract tourists the camel owners have named their camels after cricket stars like Yuvraj, Yusuf and Harbhajan.

The journey to reach Nubra valley from Leh is breathtaking and highly adventurous. To get to Nubra valley, one has to take the road through Khardung La, which is at 18380 feet and is the highest motorable road in the world. The tourist season in Nubra begins in late spring and lasts up to early October. The camels are "a good source of livelihood" for residents of Nubra valley.

As the ingenuity of "Bactrian Camel Safaris" grew in popularity, the villagers decided to register their enterprise. The local administration has helped camel owners to form camel unions. And thus the "Central Asia Camel Safari", a registered cooperative society, came into existence in 2009. The neighboring villages namely Sumur (situated on other side of Nubra valley near Siachin base), Tigger, and Diskit also formed their own Bactrian Camel Cooperatives and Unions. The union helps to divide equally the camel safaris among different camel owners, ensuring a livelihood for all. Today these safaris, whether 
along the breathtakingly beautiful Shyok River in the Nubra valley or in areas close to the base camp of the Siachen Glacier, are a big draw with tourists.

In 2007 the rates of camel safari were Rs 150 for a 15 min of riding. The rates were revised in 2013 by a committee comprising of Sub-Divisional Magistrate, Nubra, Block Veterinary Officer, Nubra and Naib Tehsildar, Turtuk, Nubra are as Rs 180 for 15 min ride, Rs 330 for 30 min ride and Rs 570 for 60 min ride. In 2018 it is again revised and a 15-minute camel ride costs Rs 300 per rider. One Bactrian Camel on an average in a tourist season earns 1 to 2.5 lakhs of rupees and is a source of livelihood for the villagers. An average camel owner earns up to Rs 4 lakh per season. Till a decade ago, these camels were available for free. Now, each cost up to Rs 80,000.

As per personal discussion with camel farmers of Nubra and Sumoor it was observed that most of the camel breeders in addition to work of riding for the tourists have agriculture work. Some breeders give their camels to other persons on contract basis for riding. Most of the breeders have land holding from 5 to 20 kanals and one farmer was having 50 kanals of land. They grow wheat, barley, alfa-alfa, apple orchard and Khumani, potato, cabbage etc. They also grow poplar tree which is very popular and used as timber and for making of houses. The average family size of camel farmers was from 3 to 9 members. Most camel farmers have 1-3 camels but some are having 4-5 also. In addition to camels some breeders also keep cows, jo, sheep, goat and poultry. One farmer was also having horse.

Management practices- The camels are domesticated i.e. kept under semi-intensive system of management for 6-7 months (mid May to mid November). This period coincides with tourist season when the camel are used for mini safari and riding. During winter months they are let free in pasture lands/ forest (extensive system of management). Thorny bush (Leh berry or Seabuck thorn) is the main feed for camel maintained here. The camels under safari/riding were given extra supplementation with concentrate feeds. Male camels are primarily used for riding purpose. The farmers in Hunder village have about 60 male camels for riding. The breeder association has grouped them in two batches of 30 camels. One batch is allowed for two days and then given rest for two days. This also allows them to avoid competition among themselves.

Reproduction is seasonal in winter from December to February or March. The poll glands are not visible. The gestation length is about 13 months. The authors during a visit to Ladakh in the month of October performed rectal examination and diagnosed female camels as pregnant and also with no follicle on ovaries. A male was directed towards a female restrained in sitting position. It mounted and sat in copulatory position. It gives primary indication that males are capable of mounting in the month of October even when female do not have follicles (Vyas et al 2015).

Camel diseases- The discussion with camel farmers at the Hunder and Sumoor villages of Nubra valley revealed that there is no incidence of trypanosomiasis. Symptoms/ lesions similar to FMD (Lameness, ulcers and excessive salivation) and urinary tract infection were reported by farmers. Injury to eye and eyelid due to plenty of thorny bushes is a major problem. Incidences of skin and endo-parasitic infections have also been reported (Ranjan et al 2015). Digestive disorders and Calf mortality (accidental) due to drowning in river waters/ heavy water flow are not uncommon. Sporadic incidences of attack by wildlife were also reported by the camel farmers.

At the Government farm of Chuchoot, Leh, Ladakh there were 25 camels in 2013. Farm personnel reported no major clinical diseases at the farm except skin affection in few camels.

\section{Challenges before camel safari operators in Nubra valley}

The safari organisers have of late had to deal with accusations from animal rights activists that the camels are being subjected to abuse. But the camel farmers refute these allegations. Since the camel provide them livelihood their life is now dependent upon camels so it is hard to believe that they can illtreat their camels. However absence of a proper healthcare facility for the camels and proper shed or housing facility is of concern to both the camel safari runners and animal rights activists.

The camel owners are now often in conflict with the private land owners and the Forest Department because the animals trespass their fences and cause damage to their resources. Sometimes camels are hurt in the process of driving them away from the private lands. 
The inhospitable terrain posed a severe threat to the camel's existence. The newborn camel calves, unaware of their surroundings, were often drowned in the Shayok river. Those that survived frequently fell prey to wolves.

\section{Wool}

An adult camel yields an average of 2-4 kg of fine wool and around $3 \mathrm{~kg}$ of coarse wool annually, which is used extensively in the manufacture of caps, sweaters and mufflers. There should be some support for making items from the Bactrian camel hairs. Depending upon the age, the average annual hair production per camel ranges from 2.5 to $4.0 \mathrm{~kg}$. Bactrian camel's hairs are of very fine quality fiber. Highquality items like shawls, pullovers, sweaters, winter garments, coats, and caps can be made. Though this may not be economically viable as the quantity of hair obtained from one camel during summer may not be enough for weaving a pure product out of that. But with blending from another wool such as "Angora Rabbit Hairs" might make it commercially viable.

\section{Bactrian camel as draft animal}

The load carrying capacity of Bactrian camel is reported to vary between $500-600 \mathrm{~kg}$ as against the $60-70 \mathrm{~kg}$ by a pack pony. The "Defence Institute of High Altitude Research" (DIHAR), a unit of the "Defence Research and Development Organization (DRDO)" in Leh, has started research on the loadcarrying capacity of the Bactrian camels. DIHAR is currently training Bactrian camels with dromedary camels at DIHAR's lab in Leh, and the results are very encouraging. Initial observations indicate that this camel can travel up to $12 \mathrm{~km}$ at a time with a weight of $170 \mathrm{~kg}$ at an altitude of 17000 feet.

In future these camels may be introduced for patrolling the Line of Actual Control (LAC) with China to check intrusion in Ladakh and also carry 180 to $220 \mathrm{~kg}$ load of ammunition, rations and other supplies in the inhospitable terrain at 12000 to 15550 feet.

Currently, the Indian Army uses mules and ponies in the region. They have the capacity to carry about 40 $\mathrm{kg}$ of load. In comparison, the double-humped (Bactrian) camels can carry between 180-220 kg of load and can cover a distance of 10 to $15 \mathrm{~km}$ within two hours.

Following issues should be taken on priority basis by policy makers for conservation of Bactrian camel

1) Evaluation ofthe productive and reproductive performance of double humped camel and measures to improve it.

2) Collection of basic data on physiology, biochemical, management, nutrition, genetics, breeding and draught potential for future improvement.

3) Studies on the nutritional requirement of the camel, feed resource inventorization and its evaluation to devise the feeding schedules for various seasons and different physiological stages.

4) Present status of health and diseases incidence, and standardized prophylaxis and control measures.

5) Study of camel produce (Milk, fiber and dung), its evaluation and utilization for development of various products of commercial value.

6) Development of agricultural and carting implements for double humped camels for improving socioeconomic status of local people of Nubra Valley.

7) Rejuvenation of the rangelands of Nubra valley with local grasses re-seeding, planting of native and adaptable trees and bushes having feed/fodder value.

8) Introduction of new blood by importing of double hump male camels to prevent inbreeding.

9) Resting shelter/ shed for camels, calves and their saddlery at the camel safari place at Hunder in Nubra Valley. Improvement of conditions at Safari point will help in increasing the number of animals and will also lead to socio-economic upliftment of camel keepers. It will have overall impact on economy of ST population of Hundar area as their economy is based mainly on Tourism.

10) In future development of hybrid a cross between single and double humped camel may be given a thought as hybrids have been reported to have more endurance.

Bactrian camel offers a great avenue for the prosperity of people living in Nubra Valley. If taken the right measures and steps, the health of these animals can be improved while they contribute to the increasing demand for tourism. Considering how the conditions in which the locals live, we need to create a model that gives an incentive to the locals to take more care of these animals. Also, the Govt. needs to support the locals in this endeavor. Looking upon huge economic utility of Bactrian camels government funding under sheep and animal husbandry programmes should also be made available for the welfare of Bactrian camels. 
Slowly the true potential of Bactrian camels is being recognized. It is high time policy intervention should be done and a roadmap is prepared so that they can be beneficial to the local population as well as the army.

This camel is of immense interest to researchers as it can withstand temperatures as low as minus30 degrees Celsius, has high disease resistance, and has very high feed conversion efficiency. The doublehump camel can propagate naturally, roaming and grazing in the rangeland all year round without any supplementary feed. They are the only land animal who can eat snow.

The Bactrian Camels of Ladakh have the real capability of changing the economics of the Nubra Valley making the stakeholders prosperous and rich. Complete registration of the Bactrian camel, protection of community grazing areas, promotion of camel-based tourism and small cottage industry for camel products will ensure conservation of this treasurable genetic resource.

\section{References}

1) He X. 2002. Resource atlas of camels in China. Changsha: Human Science and Technology Press

2) Indra P, Magash A, Bastuuri L. 2003. Mongolia camels. Ulaanbatar, Mongolia: Munkhlin-Useg Co. Ltd. Publishing

3) Isani GB, Baloch MN 2000. Camel breeds of Pakistan. By Arab Centre for the Studies of Arid Zones and Dry Lands, Pakistan Ministry of Food, Agriculture and Livestock and Camel Applied Research and Development Network (CARDN-Pakistan/ACSAD/P 94/2000.p.1-150.

4) Khanna ND, Khan MA. 1988. The double humped camel of Ladakh. Indian Farming. 1988;6: 29-30.

5) Lensch J. 1999 The two-humped camel (Camelus bactrianus) World Animal Review Series published by FAO [Online]. Avaliable from: http://www.fao.org/docrep/X1700T/X1700T00. htm.

6) Makhdoomi DM, Gazi MA, Nabi S, Ahmad S 2013. Morphometric studies on adult double humped camel of Ladakh, India. Emirates Journal of Food \& Agriculture 23 (7): 544-548.

7) Moqaddam E, Namaz-Zadeh KP 1998. An introduction to various breeds of camel in Iran. Mazraeh (Farm): Analytical and Educationsl Magazine. February and March No. 11: 73-78.

8) Ranjan R Narnaware SD, Sawal RK, Nath K 2015. A report on common health problems in Indian Bactrian camels (Camelus bactrianus). Journal of Camel Practice and Research 22 (2): 223-225.

9) Shergojry SA, Akhoon ZA, Mubarak T and Namgyal D 2017. Socio-economic impact of livestock in tribal areas of Leh. Journal of Krishi Vigyan, 6(1): 187-190.

10) Vyas S, Sheikh FD, Singh S, Sena DS, Bissa UK, Sharma N 2014. Sea Buckthorn (Hippophae rhamnoides)- An important fodder for Bactrian camel in Ladakh region. Journal of Camel Practice and Research, 21(1): 89-91.

11) Vyas S, Sharma N, Sheikh FD, Singh S, Sena DS, Bissa UK 2015. Reproductive status of Camelus bactrianus during early breeding season in India Asian Pacific Journal of Reproduction 4(1):61-64 